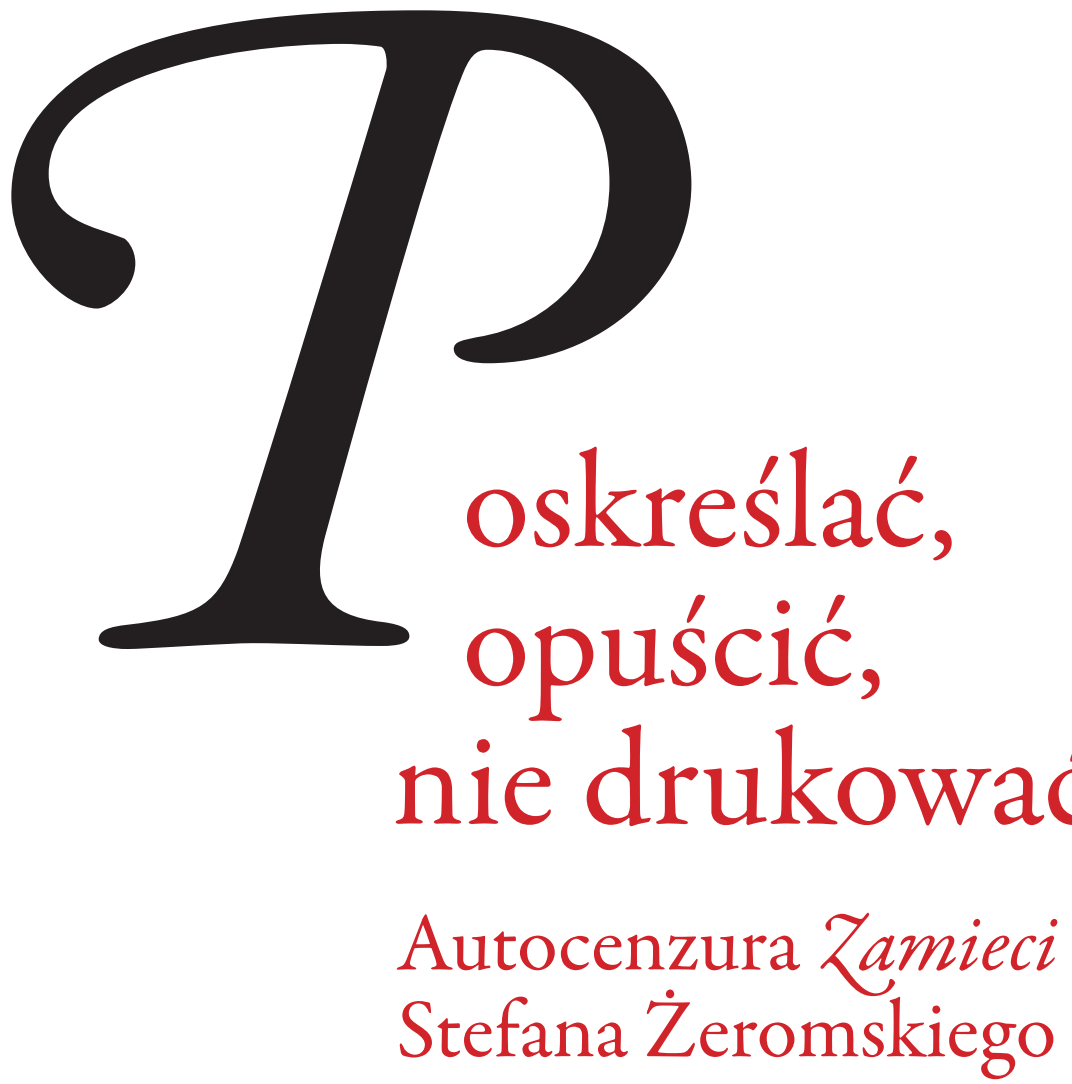

Stefan Żeromski należy do tych twórców przełomu XIX i XX wieku, nad którymi cenzura rosyjska (po 1945 roku również PRL-owska) roztoczyła szczególną opiekę․ W fatalistycznej interpretacji przyjaciela pisarza, Zygmunta Wasilewskiego, Żeromski już jako debiutant miał „pech do cenzury”. Ten „pech”, przejawiający się w czujności (a z biegiem czasu i wraz ze wzrostem popularności autora $L u d z i$ bezdomnych, nawet w przeczuleniu) cenzorów wobec jego dzieł, miał swoje źródło w sposobie pojmowania przez Żeromskiego roli pisarza i zadań literatury. Od początku rozumiał on twórczość literacką jako rodzaj społecznego i narodowego posłannictwa, zabierania głosu w najistotniejszych dla Polski i Polaków sprawach. Dlatego był niewygodny (bywał i niepożądany) dla władz - najpierw zaborczych, później partyjno-państwowych.

Społeczno-polityczna tematyka większości utworów Żeromskiego sprawiła, że pisarz niemal od początku, od zbioru Rozdzióbia nas kruki, wrony, miał problemy z uzyskaniem zgody na publikowanie w granicach byłego Królestwa. Niejednokrotnie był zmuszony wydawać swoje utwory poza zasięgiem carskiej cenzury - w prasie poznańskiej oraz w Krakowie i we Lwowie. Tak było m.in. w przypadku wspomnianego tomu nowel i opowiadań (Kraków 1895), Syzyfowych prac (Lwów 1898), Róży (Kraków 1909), Urody życia (Kraków 1912). Teksty, które otrzymywały zezwolenie na druk w Warszawie, często ukazywały się albo w postaci okrojonej (Wierna rzeka, Warszawa 1912), albo mocno zmienionej przez autora (Andrzej Radek, czyli Syzyfowe prace, Warszawa 1909) bądź redaktorów pism (ingerencje redaktora „Głosu” Józefa Karola Potockiego w debiutanckie nowele pisarza) $)^{3}$. 
Żeromski, który z patriotycznego nachylenia swoich prac nie chciał zrezygnować, buntował się przeciwko konieczności dostosowywania tekstów do wymagań carskich urzędników. Męczył go przymus używania języka ezopowego, uciekania się do różnego rodzaju fabularnych i stylistycznych niedomówień i aluzji. Dziewiątego października 1890 roku zapisał w Dziennikach: „Boże, usuń z Warszawy cenzurę! Niepodobna pisać w tych kleszczach, trzeba smażyć mózg nad wynalezieniem wyrazów, które by nic nie mówiły i które by mówiły wszystko. Najczęściej też wynajdzie się takie wyrazy, które nic i nikomu nie mówią"

Podobnie reagował na ingerencje cenzorów, na wymuszanie skreśleń i opuszczeń, które zniekształcały i kaleczyły jego utwory. W Dziennikach narzekał na „wyrżnięcie prawie wszystkiego" z młodzieńczej noweli Psie prawo 5 . W lipcu 1909 roku pisał do żony Oktawii o „masakrowaniu” Syzyfowych prac przez warszawski tygodnik „Sztandar”, który publikował pierwsze legalne w zaborze rosyjskim wydanie powieści ${ }^{6}$. Trzy lata później w liście do Stanisława Piołun-Noyszewskiego oceniał „cenzuralną", czyli mocno skróconą i miejscami pozbawioną sensu, edycję Wiernej rzeki jako „nic niewartą"”.

Żeromski pisał i wydawał pod presją restrykcyjnej, ostrej rosyjskiej cenzury niemal dwadzieścia pięć lat. Cenzura niemiecka, krótko obowiązująca na ziemiach dawnego Królestwa, objęła swoją kontrolą tylko dwie powieści pisarza: wydanie książkowe Nawracania Judasza (1916) oraz pierwodruk czasopiśmienniczy i książkowy Zamieci (1916). Wykazała się wobec tych tekstów łagodnością - usunęła jedynie z Zamieci (i wyłącznie z jej edycji książkowej) jeden krótki fragment, zawierający ostrzeżenie przed ekspansją ekonomiczną Niemców na tereny górnicze Śląska i Galicji. Cenzurę urzędową wspomógł jednak nieoczekiwanie autor, który obszedł się z pierwodrukami Zamieci niemal z taką samą bezwzględnością, jak cenzorzy rosyjscy z warszawskim wydaniem Wiernej rzeki.

Dzieje wydawnicze Zamieci - powieści opowiadającej historię obsesyjnej zazdrości Ryszarda Nienaskiego o Xenię Granowską - są o tyle wyjątkowe, że stanowią jedyny w twórczości Żeromskiego przypadek autocenzury nie ze względów politycznych, tylko obyczajowych. W dodatku znaczne okaleczenie tekstu nie było wynikiem żądań czy choćby oczekiwań jakiejkolwiek instytucji, ale zostało przeprowadzone z inicjatywy autora. Z listu Żeromskiego do wydawcy Zamieci, Jakuba Mortkowicza, z 18 kwietnia 1916 roku wynika, że pisarzowi zależało na dostosowaniu tej powieści - w zasadniczym swym kształcie przygotowanej jeszcze przed wojną - do warunków historycznych: autor chciał złagodzić brutalny język oraz wyeliminować jaskrawe erotyczne sceny, zupełnie niestosowne w obliczu wojennych doświadczeń czytelników („Przyszedłem do przekonania, że żadną miarą w dzisiejszym czasie nie można tego w całości drukować. Sceny miłosne trzeba poskreślać, o ile się tylko da. Są to rzeczy na teraz niemożliwe”) ${ }^{8}$. Choć ta motywacja nie dziwi, to jednak zaskakuje strategia przyjęta przez Żeromskiego wobec własnego utworu: nagłość jego decyzji oraz ogromny zasięg - jak miało się później okazać - nieodwracalnych ingerencji.

Żeromski uznawał Zamieć za powieść przedwojenną. Świadczy o tym informacja umieszczona pod drukowanym tekstem, niemająca nic wspólnego z rzeczywistym ukończeniem prac nad utworem: „Wyżnie Hagi, w lipcu 1914 roku”.

Nad brulionową wersją tekstu, wówczas jeszcze traktowanego nie jako samodzielna całość, ale drugi tom obszernej powieści zatytułowanej Walka z szatanem, pisarz pracował w Zakopanem od grudnia 1913 do 8 lutego 1914 roku. Brulion
całej Walki z szatanem, liczący sześć zeszytów, Żeromski zabrał ze sobą na początku marca do Florencji, gdzie rozpoczął przepisywanie, czyli przygotowywanie czystopisu pierwszego tomu (późniejszego Nawracania Judasza). Wybuch wojny przerwał te prace: do sierpnia 1914 roku Żeromski zdążył przesłać Jakubowi Mortkowiczowi, z którym na początku roku podpisał umowę na wydanie Walki $z$ szatanem, czystopis obejmujący około dwie trzecie tekstu pierwszego tomu.

Wybuch wojny zastał pisarza w Wyżnich Hagach po słowackiej stronie Tatr. Gdy w połowie sierpnia Żeromski stamtąd w pośpiechu wyjeżdżał, nie wziął ze sobą rękopisu Walki z szatanem - pozostawil go pod opieką właściciela hotelu, w którym mieszkat, Aladara Polnischa. Autograf ten w listopadzie 1914 roku przeniósł przez góry przewodnik tatrzański, Jakub Wywrotko. Piętnastego listopada Żeromski wystawił mu pisane po polsku i po niemiecku upoważnienie:

Upoważniam przewodnika po górach Jakuba Wywrotkę do otrzymania od pana Aladara Polnischa, właściciela ho- 
telu w Felsö-Hági (Hoche-Tatra, Komitat Zips), rękopisu mojego romansu pod tytułem Walka z szatanem, który to utwór literacki zostawiłem na przechowanie u p. Aladara Polnischa w sierpniu rb. Przewodnik Jakub Wywrotko ma przynieść do mnie rękopis rękopis [sic!] romansu Walka z szatanem do Zakopanego'.

Wszystko wskazuje na to, że dopiero zimą 1914 roku w Zakopanem Żeromski mógł rozpocząć przepisywanie drugiego tomu Walki z szatanem (późniejszej Zamieci). Nie wiemy, jak przebiegały te prace, ale wydaje się, że do jesieni 1915 roku czystopis tych partii powieści nie mógł być jeszcze gotowy gdy pisarz wznowił wówczas z Mortkowiczem rozmowy w sprawie druku Walki z szatanem, informował go o ciągłym przerabianiu rękopisu: „Część drugą [Walki z szatanem - B. U.] całą w rękopisie posiadam u siebie i ze trzysta razy ją poprawiałem i przeczytałem"10.

Nie dysponujemy żadnymi dokumentami z tych ponownie podjętych rozmów wydawniczych, ale prawdopodobnie to Mortkowicz wpadł wtedy na pomysł, by Walkę z szatanem rozbić na dwie różne powieści, osobno tytułowane i wydawane. To, co wcześniej miało być tomem pierwszym Walki z szatanem, stało się Nawracaniem Judasza, to, co miało być tomem drugim - Zamiecią. Ponieważ Mortkowicz miał już cały czystopis Nawracania Judasza, proces wydawniczy przebiegł dość sprawnie i w sierpniu 1916 roku powieść ukazała się na rynku. Dużo bardziej kłopotliwe i skomplikowane okazały się dzieje wydawnicze Zamieci.

Zapewne dopiero w grudniu 1915 lub w styczniu 1916 roku Żeromski przesłał Mortkowiczowi czystopis Zamieci. W zeszycie pierwszym miesięcznika „Myśl Polska”, którego Mortkowicz był redaktorem, ukazała się zapowiedź: „W następnym zeszycie »Myśl Polska « rozpocznie druk nowej powieści Stefana Żeromskiego pt. Zamieć”. Na anons zamieszczony w styczniowym numerze „Myśli Polskiej” zareagowali wydawcy krakowskiej „Nowej Reformy” - 28 lutego 1916 roku pisał do Żeromskiego Władysław Prokesch, prosząc w imieniu redakcji o zgodę na przedruk powieści i myląc jednocześnie jej tytuł:

Wyczytawszy w dziennikach warszawskich zapowiedź nowej pańskiej powieści Powódź [sic!], pospieszam zapytać w imieniu „N[owej] Reformy”, czyby Pan nie zechciał ofiarować nam przedruku? Czytelnicy nasi stęsknili się za waszym piórem, więc z radością pragnęlibyśmy te tęsknoty ich uspokoić. W razie pomyślnej dla nas decyzji, zechciejcie łaskawie podać wasze warunki ${ }^{11}$.
List zawierający zgodę na przedruk Żeromski przesłał na ręce redaktora „Nowej Reformy”, Michała Konopińskiego, 2 marca 1916 roku. W liście tym ustalał wysokość honorarium oraz sposób dostarczania tekstu. Ponieważ czystopis całej Zamieci przekazał Mortkowiczowi, który w zeszycie drugim (lutowym) istotnie rozpoczął publikację powieści, a odpisu - jak zapewniał - nie miał, proponował redaktorom „Nowej Reformy”, aby początek tekstu przedrukowali z „Myśli Polskiej” oraz zażądali od Mortkowicza arkuszy korekcyjnych dalszych odcinków ${ }^{12}$.

Konopiński odpowiedział 10 marca. Zgadzał się na warunki finansowe Żeromskiego, prosił jednak o pomoc w zdobyciu zeszytów „Myśli Polskiej”, których dystrybucję utrudniała wojna: „Druk Zamieci pragnęlibyśmy rozpocząć jak najrychlej, ale niestety nie mamy dotąd w ręku »Myśli Polskiej « za m[iesiąc] luty i marzec, w których podobno mieści się początek powieści. Dlatego niezależnie od starań, jakie na własną rękę celem otrzymania »Myśli« poczynimy, bylibyśmy obowiązani, aby Pan zechciał także ze swej strony nam dopomóc i w razie otrzymania odnośnych nrów drogą prywatną bezzwłocznie nam ich udzielić"13.

Na prośbę albo redakcji „Nowej Reformy”, albo pisarza Mortkowicz zlecił sporządzenie maszynopisu Zamieci ${ }^{14}$ i w częściach wysyłał go - znów nie wiadomo - albo do redakcji dziennika ${ }^{15}$, albo bezpośrednio do autora. Osiemnastego kwietnia Żeromski informował Mortkowicza: „Rękopis otrzymałem w trzech przesyłkach i dziękuję za to" ${ }^{16}$.

Przesłanie „maszynowego rękopisu” Zamieci stanowiło punkt zwrotny w procesie powstawania i wydawania powieści. Na otrzymaną kopię Żeromski spojrzał bowiem zupełnie inaczej niż na przekazany Mortkowiczowi zaledwie trzy-cztery miesiące wcześniej czystopis. Wiadomo, że pisarz oddawał do wydawnictwa utwory, których dojrzałości w danym momencie był pewien ${ }^{17}$. Brulion Zamieci - o czym była już mowa - powstał na przełomie 1913 i 1914 roku. Później wielokrotnie ten brudnopis sczytywał i poprawiał, by ostatecznie, w grudniu 1915 lub w styczniu 1916 roku, ukończyć czystopis. Wydaje się, że ów czystopis nie odbiegał zbyt daleko od przedwojennej roboczej wersji powieści, że przez dwa lata pracy nad tekstem, kontynuowanej już przecież w dramatycznych warunkach wojennych, Żeromski nie zmienił zasadniczo ani jego treści, ani formy. Od początku była to przede wszystkim ekspresyjna, miejscami nawet wulgarna opowieść o miłości i zazdrości młodego idealisty, Ryszarda Nienaskiego, do pięknej, lecz zepsutej, adorowanej przez wielu mężczyzn Xeni Granowskiej. 
Nagle teraz, w kwietniu, gdy trwa już pierwodruk czasopiśmienniczy Zamieci w prasie warszawskiej i właśnie rozpoczyna się przedruk w prasie krakowskiej, pisarz kategorycznie zakazuje publikacji powieści w kształcie utrwalonym w czystopisie. Swoją decyzję uzasadnia tym, że w warunkach wojny nie może drukować powieści zdominowanej przez wątki milosne, że w obliczu straszliwych zniszczeń i traumatycznych doświadczeń tysięcy ludzi zupełnie nie na miejscu jest eksponowanie cierpień chorego z zazdrości Nienaskiego. Żeromski ma również poważne zastrzeżenia do formy ekspresji panującej w utworze - do brutalnego języka i dosadnych sformułowań powiązanych ze sferą erotyki i seksu.

Trudno powiedzieć, dlaczego wcześniej pisarza nie raziły dysproporcje zachodzące między światem przedstawionym Zamieci a światem realnym i rzeczywistością wojny. Jego decyzja, by poddać tekst daleko idącej cenzurze, mającej na celu usunięcie lub zatuszowanie kontrowersyjnych fragmentów, była jednak nieodwołalna. Nie mogąc osobiście dokonać skrótów (pisarz mieszkał w Zakopanem, „Myśl Polska” była wydawana w Warszawie), w liście z 18 kwietnia 1916 roku zażądał od Mortkowicza, by ten wykreślił lub zmienił wiele fragmentów tekstu - by wyeliminował całe rozdziały i zgodnie z własnym wyczuciem złagodził język powieści:

W rozdziale szóstym wydrukować do słów: „W sercu niósł śmierć, w oczach wielorakie zewnętrzne połyski...”. Potem wszystko do końca rozdziału skreślić, nie drukować. (Jest to miejsce, gdzie Xenia ze swą towarzyszką wyszła z kawiarni, a Nienaski ją śledzi). W rozdziale siódmym zacząć dopiero od słów: „Był już ruch w mieście, gdy Nienaski...”. Ustęp poprzedzający te słowa opuścić i nie drukować. Rozdział ósmy i dziewiąty w całości opuścić i nie drukować. Wydrukować cały rozdział z opisem śmierci Ogrodyńca. Wydrukować opis wizyty Xeni i Nienaskiego u jej ojca w więzieniu. Wszystko, co potem następuje, aż do trzeciej części powieści, bezwarunkowo opuścić i nie drukować. Proszę o to najusilniej! Część trzecią całą wydrukować. Tylko opis śmierci Ogrodyńca, wizyty w więzieniu i całą trzecią część proszę przepisać i nadesłać do „Reformy”.

Proszę o dokonanie tych skreśleń wprost jako dowód życzliwości Pana dla mnie. W książce to się może potem ukazać w innym czasie, obecnie jednak i druku książki proszę nie zaczynać bez widzenia ze mną. Dla „Reformy” jeszcze to bardziej skreślam. [...]

W tym, co pozostanie po skreśleniach, może Sz. Pan zechce wymazać wszelkie jaskrawizny w wyrażeniach albo zwroty niepasujące do całości po dokonaniu skreśleń. Gdy sam tego zrobić nie mogę, upoważniam Sz. Pana do tych skreślen ${ }^{18}$.

Żeromski naciskał na Mortkowicza, kilkakrotnie ponawiał swoje żądania. Według świadectwa córki wydawcy wysłał wówczas, w okolicy 18 kwietnia, „szereg kartek pocztowych” do jej ojca. „Wszystkie pisane są po niemiecku, stosownie do rozporządzeń wojennych, wszystkie na jeden ton w skąpych zdaniach powtarzają rozpaczliwą prośbę o skróty" - pisze Hanna Mortkowiczówna ${ }^{19}$. Cytuje te, w których znów pojawia się żądanie wydrukowania rozdziału szóstego tylko do słów: „W sercu niósł śmierć. W oczach wielorakie zewnętrzne połyski”, oraz prośba o rozpoczęcie rozdziału siódmego dopiero od słów: „Był już ruch w mieście, gdy Nienaski...” ${ }^{20}$

Wydaje się, że Mortkowicz niechętnie godził się na skreślenia. Z przytoczonej przez Mortkowiczównę ostatniej niemieckojęzycznej kartki pisarza wynika, że wydawca bezskutecznie zabiegał o cofnięcie zakazu druku naznaczonych fragmentów. W odpowiedzi na niezachowany list Mortkowicza Żeromski pisat:

Wielce Szanowny Panie!

Otrzymałem list z 11 maja. Osobiście jest dla mnie absolutnie niemożliwe, abym mógł zezwolić na druk powieści w całości, bez tych skrótów, jakie poczyniłem. [...] Uprzejmie i usilnie proszę więc Pana o usunięcie i niedrukowanie wszystkiego, co zaznaczyłem do skreślenia ${ }^{21}$.

W „Myśli Polskiej” wyszły tylko cztery części Zamieci. Zeszyty z lutego i marca ukazały się, zanim Żeromski postanowił tekst skrócić do zeszytu kwietniowego, którego druk ukończono 2 maja 1916 roku, Mortkowicz żadnych zmian wprowadzić już nie zdążył. W kolejnych zeszytach „Myśli Polskiej" został więc zachowany tekst czystopisu - są to jedyne pełne, nieocenzurowane przez autora fragmenty powieści, jakie opublikowano.

Żądania Żeromskiego Mortkowicz mógł spełnić dopiero w zeszycie majowym, który z drukarni wyszedł z dużym opóźnieniem - 3 lipca 1916 roku. Ponieważ czystopis ani maszynowy odpis Zamieci nie zachowały się, trudno dziś ze stuprocentową pewnością ocenić skalę cięć dokonanych przez Mortkowicza w tym odcinku. Jest też prawdopodobne, że ów jedyny skrócony wobec czystopisu odcinek Zamieci w „Myśli Polskiej" (dalsze odcinki już się nie ukazały) był przedrukiem z „Nowej Reformy”. Na kopii rękopisu przeznaczonej dla krakowskiego dziennika Żeromski osobiście nanosił poprawki. 
Choć początkowo, chcąc zapewne uspokoić Mortkowicza, zarzekał się, że „dla »Reformy« jeszcze to bardziej skreśla”, wkrótce okazało się, że gdy nie musiał nikomu zlecać mechanicznego usuwania całych rozdziałów, był w stanie częściowo scalić tekst: jeszcze w kwietniu uważał „druk tego utworu za druk wyjątków z całości”, ale już 2 czerwca wyrażał nadzieję, że po wprowadzeniu niezbędnych skreśleń zdoła jednak „uratować całą powieść"22. Dlatego w czerwcu prosił listownie wydawcę, by ten nie cenzurował już tekstu samodzielnie, ale „dalszy ciąg [w „Myśli Polskiej”] podał według tekstu »Reformy«”. Przekonywał przy tym, że - mimo pozorów przedruku - w rzeczywistości Mortkowicz nadal pozostaje dyspozytorem rękopisu, a cała sprawa dotyczy czysto technicznego „ułatwienia w otrzymaniu poprawnego tekstu" ${ }^{23}$.

Ów „poprawny”, czyli skrócony i złagodzony, tekst Zamieci w całości opublikowała „Nowa Reforma”, a następnie - z dość dużymi zmianami, ale nie w zakresie objętości tekstu, tylko języka - Mortkowicz opublikował w wydaniu książkowym, które ukazało się w październiku 1916 roku. Do żadnej z późniejszych edycji Zamieci autor nie przywrócił ocenzurowanych przez siebie fragmentów, choć miał taką możliwość. Tekst powieści utrwalił się więc w wersji okaleczonej, niepełnej, miejscami nielogicznej, ale zaakceptowanej przez pisarza.

Nie dysponujemy dziś czystopisem Zamieci, który pozwoliłby zrekonstruować pełną wersję powieści. Zachowały się natomiast: brulion utworu ${ }^{24}$, początkowe nieocenzurowane fragmenty tekstu z „Myśli Polskiej” oraz szczątkowe relacje córki wydawcy, Hanny Mortkowiczówny, na temat czystopisu. Materiały te dają pewne wyobrażenie o pierwotnym kształcie Zamieci oraz o zakresie i kierunku wprowadzonych przez Żeromskiego zmian.

Wydaje się, że pisarz tonował przede wszystkim sposób kreacji Xeni Granowskiej. Zarówno w brulionowej, jak i w drukowanej wersji utworu kreacja ta jest uzależniona od perspektywy szalejącego z zazdrości Ryszarda Nienaskiego, który najpierw całymi tygodniami daremnie poszukuje Xeni w Paryżu, a następnie śledzi ją i upewnia się o jej niemoralności. Takie ujęcie sprawia, że Xenia - nawet w ocenzurowanym przez autora tekście - jest przedstawiana w bardzo niekorzystnym świetle. Wiosną 1916 roku Żeromski bezwzględnie jednak skreślał i usuwał te zdania oraz większe partie tekstu, które ów wizerunek wyostrzały, które jeszcze w czystopisie sugerowały prostytuowanie się bohaterki i jej chorobę weneryczną, relacjonowały rozliczne przypadkowe i umówione spotkania dawnej narzeczonej Ryszarda z mężczyznami (w kabaretach, podrzędnych teatrzykach, restauracjach, na ulicach), opowiadały o kontaktach dziewczyny ze stręczycielką paryską i o jej wizycie w domu publicznym.

W zeszytach 2-4 „Myśli Polskiej”, w których był drukowany tekst czystopisu, znajduje się wiele określeń i zdań obraźliwych dla Xeni („Zginęła jedna kobieta, »puściła się« jedna więcej dziewczyna?”, z. 2; „Widział Xenię w osobie każdej narożnej ulicznicy - i omdlewał z rozpaczy”, z. 3) - z późniejszych wydań albo w całości usuniętych, albo zachowanych w neutralnym kontekście (w „Nowej Reformie” tylko: „Zginęła jedna kobieta”). Kwietniowy zeszyt „Myśli Polskiej” zawierał sceny dialogowe między bohaterami, roztrząsające dość szczegółowo sprawę pocałunków Xeni z przystojnym żonatym adwokatem w samochodzie oraz w jego kancelarii, a także podejmujące temat erotycznych ekscesów Ryszarda w Posusze („Więc to pani Saba i Lenta opowiadały pani, że je obiedwie naraz zaczepiałem w karecie... A którąż to najpierw? Nie mówiły tego?”, z. 4). Rozdziały Zamieci w miesięczniku nie były numerowane, ale $\mathrm{z}$ treści odcinka zamieszczonego w zeszycie czwartym wynika, że ów rozdział szósty, którego druk Żeromski chciał przerwać na słowach „W sercu niósł śmierć. W oczach wielorakie zewnętrzne połyski" - został opublikowany w całości. To w tych fragmentach znajdują się wypowiedzi Nienaskiego sugerujące prostytuowanie się Xeni i jej chorobę weneryczną („To ona mnie na jutro... Na tę godzinę czwartą... Bagatela! A dziś ten! Teraz się tam właśnie przy nim rozbiera... [...]. Nie, moja panno! Nic z godziny czwartej! Jeszcze bym ci się dał skusić... Jeszcze bym się tutaj w tym Paryżu zaraził... Zaraził... od Xeni...”). Do szóstego lub siódmego rozdziału Zamieci należała też długa scena rozmowy Ryszarda z odźwierną domu, w którym mieszkały Xenia i fotografka, Teresa Neville. Scena ta kończy odcinek powieści drukowany w kwietniowym zeszycie „Myśli Polskiej”. Z wypowiedzi odźwiernej wynika, że do mieszkania Teresy i Xeni bardzo często przychodzą mężczyźni. A cały sens rozmowy jest taki, że Nienaski zadaje w końcu pytania o to, czy Neville wykonuje zdjęcia pornograficzne oraz czy Xenia, zameldowana jako Celide Boranelli, ,jest osobą lekkich obyczajów”.

Porównanie odcinka Zamieci ogłoszonego w zeszycie piątym „Myśli Polskiej” z odpowiadającymi mu felietonami „Nowej Reformy” dowodzi, że w obu pismach ogłoszono tekst z tymi samymi opuszczeniami wobec jedynej wcześniejszej 
wersji dzieła, jaką dziś dysponujemy, czyli wobec brulionu. Do żadnego z czasopism nie wszedł zatem fragment, który w brudnopisie nie został przekreślony i znajduje się bezpośrednio po scenie rozmowy Nienaskiego z odźwierną: wypełniają go gorzkie rozmyślania Ryszarda, przekonanego o rozwiązłości Xeni - są tu oskarżenia o oszustwo i cynizm Xeni, która uśmiechem pokrywa „kloakę rozpusty”; rozterki, czy ratować jeszcze dziewczynę, czy też oddać ją „diabłu” i „paryskiej rozpuście”; refleksje o klęsce i przegranej ${ }^{25}$.

Hanna Mortkowiczówna, która widziała kopię czystopisu Zamieci, twierdziła, że w zeszycie piątym „Myśli Polskiej” „zachowane $[. .$.$] zostały przed słowami: »Był już ruch w mieście,$ gdy Nienaski... « dwa drobne ustępy malujące jego stan duchowy po przekonaniu się o »rozpuście « Xeni, natomiast poprzedni dłuższy ustęp, będący gwałtownym wybuchem pogardy dla kobiet, skreślono zupełnie, nie wszedł on później nigdy do wydania książkowego" ${ }^{26}$. Ten ustęp jest jedynym fragmentem kopii czystopisu, jaki Mortkowiczówna w swoim artykule przedrukowała, i z całą pewnością stanowi on rozbudowaną i stylistycznie zmienioną wersję przemyśleń Nienaskiego z brulionu:

We krwi kobiet leży rozpusta. Tak się zdaje... Skoro tylko raz poczują smak rozpusty, już ich nic nie może powstrzymać na tej pochyłej równi życia. Chciałoby się władać duszą kobiety! Cóż za naiwne uroszczenie! Przecie ona co dzień, a może i co godzina, mieć może nowy świat zachwytu z nowym, nieznanym, coraz piękniejszym, coraz ciekawszym, coraz bardziej tajemniczym mężczyzną! Naucz się, policjancie - mówił do siebie - że to, coś w zaślepieniu poczytywał za wybłysk promienia łaski bożej, za miłość świętą człowieka do człowieka, ukazującą swe oblicze raz na życie - to było sztucznie zrobione oszustwo, wystudiowany figiel. W ten sposób ośle[pia] się oczy prostaków blaskiem i ukrywa pod nim kloakę rozpusty. Tego się dowiedz! [...]

Można teraz było do woli rozmyślać nad pokonaniem tej niemocy, która człowiekiem ciska jak martwym polanem, to tu, to tam. Widział, że na tę niemoc nie ma w sobie tężnej siły. Jakże? Oddać Xenię? Oddać ją diabłu? Odstąpić i sprzedać miastu Paryżowi do codziennego użytku? Ją, tę samą, co w Luksemburskim Ogrodzie czegoś gorzko płakała, wręczyć paryskiej rozpuście? Zaczęło w nim wszystko kipieć i szaleć! Łkanie, jęk, potoki przekleństw. Uczucie, jakby pękały żyły i krew uchodziła.

A więc wydrzeć ją diabłu? Jak? Jakim sposobem? Co zrobić, żeby nie była sobą, żeby nie czuła szczęścia wtedy i tam, gdzie i kiedy je czuje? Co zrobić, żeby nie była z tamtym, którego zwabiła do siebie? - Pusty śmiech.
Wolny jest przecie wybór. Ma przecie człowiek prawo do rozpusty. Może czuć rozkosz, gdy ją czuje. Więc jakże walczyć? Jaką bronią? ${ }^{27}$

Prawdopodobnie rozdziały ósmy i dziewiąty, które w kwietniu na żądanie pisarza Mortkowicz miał całkowicie wykreślić, po poprawkach autora w znacznej części ocalały i weszły do pierwodruków czasopiśmienniczych (a następnie również do wydań książkowych). Ponieważ tym razem Żeromski nie rezygnował z całych partii tekstu, tylko poddawał je przeróbkom - przeróbkom jednak pośpiesznym, bo redaktorzy „Nowej Reformy” ponaglali ${ }^{28}$ - ślady cięć są dużo wyraźniejsze zarówno w zakresie fabuły, jak i struktury utworu. W obu pismach i w wydaniu książkowym wydrukowano skrócony względem brulionu rozdział opowiadający o dwuznacznym zachowywaniu się śledzonej przez Ryszarda Xeni w kawiarniach, restauracjach, teatrach, kabaretach (z korespondencji z Mortkowiczem wynikałoby, że był to rozdział ósmy). Żeromski częściowo usunął, częściowo przerobił zdania i akapity zawierające zbyt dosadne oskarżenia Xeni o niemoralność i rozpustę. W brulionie zachował się np. nieprzekreślony, możliwe zatem, że przeniesiony do czystopisu fragment:

Jadła obiad, rzucała powłóczyste spojrzenia w zamian za powłóczyste spojrzenia współbiesiadników. Stał w taki sposób za oknem na wprost Justyny [Xeni] siedzącej w głębi sali, że jej spojrzenie skierowane na jakiegoś młodzieńca, który siedział właśnie pod tym oknem, skierowane było jak gdyby w to okno.

Nienaski widział każde kokieteryjne wzniesienie jej oczu, każdy gest i minę nadobną. Była w tym pewna niedościgła ujemna rozkosz. Nasycał się widokiem metody spojrzeń kuszących, studiował całą sumę sposobów wabienia, udawania uczuć, tworzenia sztucznych niby-wzruszeń, zatapiania wzroku we wzroku. Śmiał się serdecznie, mając taką wyborną lekcję owej panny Justyny [Xeni], takie bezwiedne zeznanie przez nią samą złożone, czym ona jest właściwie ${ }^{29}$.

W druku fragment ten, po niewielkich przeróbkach stylistycznych, kończy się na zdaniu: „[...] jej wejrzenie skierowane na jakiegoś młodzieńca, który wieczerzał właśnie pod oknem, zwrócone było jak gdyby w jego stronę ${ }^{30}$. Przykłady podobnych skreśleń i eliminacji w drukowanym tekście Zamieci w porównaniu z wersją brulionową można mnożyć. Najbardziej radykalnie Żeromski zaingerował w przypuszczalny rozdział ósmy, w którym przerwał - w sposób automatyczny, wstawiając $\mathrm{w}$ to miejsce wielokropkową pauzę $e^{31}-$ scenę powrotu Xeni 
i Teresy do mieszkania w towarzystwie jakiegoś blondyna. Na skutek tego zabiegu zatarła się motywacja wizyty uzbrojonego Nienaskiego u dziewczyny (z brulionu wynika, że Ryszard idzie w nocy z rewolwerem do Xeni, chcąc ją przyłapać z owym mężczyzną i w dramatyczny sposób zakończyć swoją udrękę), zniknęly też niektóre partie dialogowe w scenie nocnej rozmowy bohaterów.

Mniejsze skreślenia objęły przypuszczalny rozdział dziewiąty, przedstawiający pierwszą scenę miłosną między bohaterami. Żeromski ocenzurował przede wszystkim te zdania, które mocniej odnosily się do erotyki i cielesności („,Panował nad nią, nad jej prześlicznym, rozżarzonym ciałem - mógł je pieścić bez oporu i bez protestu") $)^{32}$, wyrzucił także kończącą rozdział, kompromitującą prośbę Xeni o pieniądze:

- Panie!

- Słucham.

- Niech mi pan da pieniędzy...

Te słowa zamroczyły go nie gorzej od uderzenia pałką w czerep. Cóż za rozczarowanie znowu! Jaki cios! Sięgnął do kieszeni, wydobył z pugilaresu sto franków i pokazał jej papier z pytaniem:

- Czy wystarczy?

Skinęła głową dość pogardliwie. Głuche jakoweś uczucie ciemną barwą napełniło jej oczy ${ }^{33}$.

Te partie tekstu, których pierwodruk czasopiśmienniczy był kontynuowany tylko w „Nowej Reformie”, nie zawierają już żadnych nieaprobowanych przez pisarza fragmentów. Nie ma nawet tych akapitów czy zdań zachowanych w brulionie, które fabularnie wydają się konieczne, tłumaczą bowiem sytuacje i motywują zachowanie bohaterów - przypuszczalnie były więc obecne również w czystopisie wysłanym do Mortkowicza na przełomie 1915 i 1916 roku. Tekst drukowany nie wyjaśnia np., na czym polega wychwycona przez Xenię aluzja Nienaskiego do listu pani Sabiny Topolewskiej. W liście tym pani Sabina była uprzejma pouczyć Xenię: „Maleńka powinna co najmniej sześciu takich [jak Nienaski] drabów zedrzeć, zanim się takiemu odda na stałą żonę albo towarzyszkę" 34 , ale zdanie to zostało z druku usunięte. Aluzja ukryta w skardze Nienaskiego, że jest „»Złotym «, nim się na nic zedrze”35, pozostaje całkowicie niedostępna dla czytelnika. Niejasne jest także, skąd Nienaski zna treść korespondencji Xeni, po co i kiedy dziewczyna pokazywała mu „podskrobane” listy „,jako pisane do siebie” - usunięty wcześniejszy fragment informował o tym, że Xenia, przekonana o podbojach miłosnych Ryszarda, chcąc wzbudzić jego zazdrość, wyłożyła na stół rzekomo adresowane do siebie listy miłosne. Nie wiadomo również, dlaczego Nienaskiemu tak bardzo zależy na tym, by Xenia wyprowadziła się od Teresy Neville - dopiero z dwóch zachowanych w brulionie zdań dowiadujemy się, że fotografka wykonywała zdjęcia pornograficzne („Były to same nagości, pozy kuszące i sceny najzupełniej i najwyszukaniej pornograficzne. Za głowę się chwytał, patrząc na to i myśląc, gdzie ta Xenia mieszka") ${ }^{36}$.

Największy ubytek względem brulionu nastąpił w zakończeniu części pierwszej Zamieci i dotyczył rozdziału - z całą pewnością przeniesionego do czystopisu - przedstawiającego spotkanie Xeni i Nienaskiego w domu schadzek u hrabiny Ravelsky ${ }^{37}$. W cytowanym już liście do Mortkowicza z 2 czerwca 1916 roku Żeromski pisał: „Nie widzę zupełnie »Myśli Polskiej « i nie wiem, w jakiej formie tam to jest drukowane, a to dla mnie jest formalną męczarnią. Za żadną bowiem cenę nie mogę i nie mógłbym się zgodzić na wydrukowanie pewnych scen, jak np. sceny u stręczycielki, hrabiny Ravelsky. Jest to czas absolutnie nie na takie rzeczy"38. Scena ta stanowi najmocniejszy i jednocześnie ostatni akcent wątku „rozwiązłości” Xeni. Rozgrywa się w domu schadzek prowadzonym przez niejaką hrabinę Ravelsky, która aranżuje u siebie spotkania bogatych mężczyzn z ubogimi, niemającymi rodziny, ale atrakcyjnymi i młodymi dziewczętami. Nienaski spotyka się tam z Xenią jak się ostatecznie okazuje - „niewinną dziewicą, niesplamioną męskim dotykiem”39, za to ciekawą świata i jego zakazanych uroków, gotową wypróbować nawet rolę kobiety do towarzystwa. Scena kończy się brutalnym pobiciem stręczycielki przez Nienaskiego i zabraniem Xeni z domu schadzek do kościoła Saint-Séverin ${ }^{40}$.

Z drukowanej wersji Zamieci ten długi, kilkunastostronicowy fragment został całkowicie usunięty. Pozostałością wykreślonej sceny jest - zupełnie niejasny w kontekście opublikowanego tekstu, ale dobrze umotywowany w autografie - epizod z odźwiernym, który „drwiącym, cynicznym uśmiechem” odprowadza wychodzącą z domu schadzek parę.

Takich interwencji autorskich, czyniących z Zamieci utwór fragmentaryczny, niespójny, miejscami nielogiczny, jest znacznie więcej. Gdy w kwietniu 1916 roku Żeromski podejmował drastyczną decyzję o samocenzurze tekstu, był jego zniekształcenia w pełni świadomy. „Uważam druk tego utworu za druk wyjątków z całości” - pisał wówczas do Mortkowicza i zapowiadał pełne wydanie powieści „w innym czasie” ${ }^{21}$. Nigdy jednak swojego zamiaru nie urzeczywistnił. O ile więc ocenzurowanie przez rosyjskich urzędników Wiernej rzeki czy Syzyfowych prac nie uczyniło tym powieściom bezpowrotnej szkody, w kulturze narodowej funkcjonują one bowiem w nieocenzurowanej 
galicyjskiej wersji, o tyle Zamieć zachowała się tylko w postaci okrojonej i mocno zmienionej przez autora bądź działających z jego upoważnienia wydawców.

Zbigniew Goliński we Wstępie do pierwszego tomu wydania krytycznego Pism zebranych Stefana Żeromskiego pisał, że dzisiejszy wydawca musi „starannie rozważyć, co rewindykować" w ocenzurowanych utworach pisarza, oraz że Zamieć ze względu na autocenzurę - powinna zostać „wyjątkowo potraktowana”’2 . Nie do końca wiadomo, na czym ta wyjątkowa procedura miałaby polegać. Dostępne przekazy nie pozwalają na odtworzenie Zamieci w formie sprzed kwietnia 1916 roku: w egzemplarzach „Myśli Polskiej” zachował się tylko początkowy fragment nieocenzurowanej powieści (do sceny rozmowy Ryszarda z odźwierną domu Xeni i Teresy Neville), a brulion zawiera roboczą, przedfinalną, wielokrotnie zmienianą wersję utworu. Brulion ten może i powinien stanowić przedmiot tekstologicznych badań, ale nie podstawę przywróceń usuniętych fragmentów.

Jedyna ukończona wersja Zamieci to wersja ocenzurowana. Swoją wolę względem takiego kształtu powieści - w niektórych miejscach wyraźnie popsutej, ale pozbawionej najbardziej kontrowersyjnych fragmentów - Żeromski na różne sposoby potwierdził: najpierw wyraził ją w listach do Mortkowicza, później zrealizował w tekście osobiście skracanym i poprawianym dla „Nowej Reformy”, a ostatecznie utrwalił w pierwszym wydaniu książkowym powieści. Wprawdzie edycja Zamieci z października 1916 roku różni się od pierwodruku z „Nowej Reformy" i nie wiadomo, kogo obciążyć odpowiedzialnością za przeróbki: autora czy wydawcę, ale Żeromski milcząco zaakceptował wszelkie te zmiany i nigdy już później tekstu powieści nie modyfikowal. Dlatego podstawą krytycznych wydań Zamieci jest pierwodruk książkowy, a podejmowane przez edytorów próby częściowej rekonstrukcji nieocenzurowanego tekstu Zamieci zawsze przebiegają obok tekstu głównego, są do niego jedynie dodatkiem.

Stanisław Pigoń w edycjach zbiorowych dzieł Żeromskiego wydawanych pod swoją redakcją dołączał do Zamieci aneks złożony z „ustępów wyłączonych przez autora”ł3. Rejestr ten przygotował na podstawie „Myśli Polskiej” oraz artykułu Mortkowiczówny i uwzględnił w nim osiemnaście usuniętych fragmentów (pojedynczych wyrazów i zdań, ale także dłuższych ustępów) - w tym fragment wyeliminowany przez cenzurę niemiecką. Jest to niejako alternatywny tekst Zamieci, ale bardzo cząstkowy: pełny tylko do owej sceny z odźwierną, a dalej ograniczony do dwóch fragmentów przytoczonych za Mortkowiczówną - do cytowanego przez nią ustępu z rozmyślaniami Ryszarda po rozmowie z dozorczynią oraz do streszczonej sceny u hrabiny Ravelsky. Tak szczątkowy aneks Pigonia wynika z faktu, że edytor nie wiedział o istnieniu brulionów Zamieci, był przekonany, że uległy one zniszczeniu podczas drugiej wojny światowej. Pigoń nie mógł więc prześledzić kierunku zmian ani skali skreśleń w tych partiach powieści, które Żeromski zdążył ocenzurować również w „Myśli Polskiej”.

Władysława Wasilewska, której śmierć przerwała prace nad wydaniem krytycznym Zamieci w ramach Pism zebranych pod redakcją Zbigniewa Golińskiego, także planowała przygotować taki aneks. Wstępna redakcja wariantów tekstu wskazuje, że Wasilewska zamierzała z rejestru odmian wyłączyć fragmenty zachowane w „Myśli Polskiej”, ale usunięte przez Żeromskiego z innych wydań. To one miały utworzyć ów aneks - analogiczny jak u Pigonia, wersja Zamieci to wersja ocenzurowana tekstu głównego; wszystko wskazuje na to, że w żaden inny sposób Wasilewska nie zamierzała ich w swoim opracowaniu wykorzystać ${ }^{44}$.

Obecnie, w przygotowywanym na nowo wydaniu krytycznym Zamieci, postanowiono zachować tradycję aneksu, ale inaczej pomyślanego niż u Pigonia i Wasilewskiej. Tekst główny powieści oparto oczywiście na pierwodruku książkowym z października 1916 roku. Wszelkie pozostałe autentyczne przekazy drukowane, lącznie z nieocenzurowanymi początkowymi partiami Zamieci opublikowanymi w „Myśli Polskiej", włączono jednak do analizy tekstologicznej na tych samych zasadach - i wszystkie one weszły do rejestru odmian tekstu.

W aneksach zdecydowano się umieścić wyłącznie materiały z brulionu Zamieci. Są to fragmenty tekstu, które z pewnością lub przypuszczalnie znalazły się w przeznaczonym do wydania powieści autorskim czystopisie, a następnie - decyzją Żeromskiego - zostały w 1916 roku z druku wycofane i w żadnym z wydań Zamieci (ani w pierwodrukach czasopiśmienniczych, ani w edycji książkowej) się nie ukazały. Wszystkie te fragmenty należą do fabularnego wątku dziejów 
miłości i zazdrości głównego bohatera, podejrzewającego Xenię Granowską o zdradę. Nie ma wprawdzie stuprocentowej pewności, że weszły one do czystopisu (z wyjątkiem sceny rozmyślań Nienaskiego po rozmowie z odźwierną oraz sceny u hrabiny Ravelsky - te partie tekstu cytowała bowiem lub streszczała Mortkowiczówna, wspominał też o nich pisarz w listach) - jest to jednak wielce prawdopodobne. Po pierwsze, w brulionie ustępy te nie zostały przez autora przekreślone, a więc jakby zachowane dla czystopisowej wersji tekstu, po drugie, leżą one na głównej linii autocenzorskich zabiegów autora. Dodatkowym argumentem przemawiającym za obecnością tych fragmentów w czystopisie jest fakt, że fabuła wydanej powieści wyraźnie do nich nawiązuje, to znaczy, że gdyby trafily one do tekstu opublikowanego, niektóre zachowania bohaterów byłyby bardziej zrozumiałe.

Sens włączenia do wydania Zamieci brulionowych redakcji tekstu zawiera się w fakcie, że są to jedyne (poza odcinkami „Myśli Polskiej”) dostępne dziś autentyczne fragmenty utworu sprzed jego ocenzurowania. Może nie wpływają one w zasadniczy sposób na bieg zdarzeń - w obu wersjach, rękopiśmiennej i drukowanej - Xenia ostatecznie jest bowiem rehabilitowana, ale pozwalają na nieco inną interpretację powieści, naznaczając ją silnym piętnem mizoginizmu. Rekonstruowany czystopisowy tekst Zamieci dowodzi również natarczywości niektórych pomysłów literackich Żeromskiego, jak powracająca od młodzieńczego szkicu $Z$ teki obiektywisty po późny dramat Biata rękawiczka scena spotkania rodzeństwa (tu: narzeczonych) $\mathrm{w}$ domu publicznym. Fragmenty z brulionu, które z dużym prawdopodobieństwem weszły do czystopisu, warto także opublikować po to, by pokazać, że epizodyczność i niespójność Zamieci wynika nie tylko z poetyki powieści modernistycznej, ale - w dużo większym stopniu - z autocenzury tekstu i skomplikowanych losów wydawniczych dzieła ${ }^{45}$.

Summary: "Remove, omit, do not print..." Self-censorship of "Zamieć" by Stefan Żeromski

Key Words: Stefan Żeromski, Zamieć, self-censorship, nineteenth century morality, Jakub Mortkowicz

For almost twenty-five years Żeromski created and published under the pressure of restrictive and harsh Russian censorship. German censorship, which was in force in the lands of the former kingdom, supervised two novels written by the author: the book version of Nawracanie Judasza (1916) and the first printing of Zamieć (1916). Censors were not very strict - they removed only from Zamieć (from its book version) one short excerpt with a warning regarding the economic expansion of the Germans in the mining areas of Silesia and Galicia. Surprisingly, the censorship was supported by the author, who uncompromisingly treated the first printing of Zamieć - his action resembled the way in which Russian officials censored the Warsaw edition of Wierna rzeka.

The editorial history of Zamieć - a novel about Ryszard Nienaski's obsessive jealousy of Xenia Granowska - is exceptional as it presents the only one example of Żeromski's self-censorship for reasons relating to morality. Furthermore, the modification of the text was not the result of demands or expectations expressed by some institutions; it was the author himself who decided to introduce changes. In the letter addressed to the publisher of Zamieć, Jakub Mortkowicz, dated 18 April 1916, the author stated that he wanted to adjust the novel - prepared before the war - to the historical conditions: the writer wished to tone down the brutal language and erase erotic scenes which seemed inappropriate when correlated to the readers' war experience. Although his motivation is not startling, the strategy adopted by Żeromski might be stupefying: the suddenness of his decision and the great extent of his irreversible interference.

Zob. m.in. Z. J. Adamczyk, Carska cenzura wobec twórczości Stefana Żeromskiego „Rocznik Świętokrzyski” 1989, t. 16; K. Kościewicz, Intymistyka i cenzura - na przykładzie pierwszego wydania "Dzienników” Stefana Żeromskiego, w: „Lancetem, a nie maczugą". Cenzura wobec literatury i jej twórców w latach 1945-1965, pod red. K. Budrowskiej i M. Woźniak-Łabieniec, Warszawa 2012; B. Utkowska, Spormy wzorzec rusofobii. Stefan Żeromski wobec Rosji i Rosjan w „Dziennikach”, „Pamiętnik Literacki” 2013, z. 2.

Cyt. za: Z. J. Adamczyk, Uwagi wydawcy, w: S. Żeromski, Pisma zebrane, pod red. Z. Golińskiego, t. 1: Opowiadania, oprac. Z. J. Adamczyk, Warszawa 1981, s. 333.

3 Ibidem.

${ }^{4}$ S. Żeromski, Dzienników tom odnaleziony, oprac. J. Kądziela, Warszawa 1973, s. 213.

${ }^{5}$ Idem, Dzieła, pod red. S. Pigonia, wstęp H. Markiewicz, t. 6: Dzienniki, oprac. J. Kądziela, Warszawa 1966, s. 250.

${ }^{6}$ Idem, Pisma zebrane, pod red. Z. Golińskiego, t. 37: Listy 1905-1912, oprac.

Z. J. Adamczyk, Warszawa 2006, s. 182.

${ }^{7}$ Ibidem, s. 437.

${ }^{8}$ S. Żeromski, Pisma zebrane, pod red. Z. Golińskiego, t. 38: Listy 1913-1918, oprac.

Z. J. Adamczyk, Warszawa 2008, s. 327-328.

${ }^{9}$ Cyt. za: ibidem, s. 285.

${ }^{10}$ Ibidem, s. 313

${ }^{11}$ BN, rkps akc. 17 218/29.

S. Zeromski, Listy 1913-1918, s. 319-320.

BN, rkps akc. 17 218/29.

14 O tym, że był to maszynowy odpis, informowała Hanna Mortkowiczówna w artykule Dramatyczne dzieje rękopisu, „Wiadomości Literackie” 1932, nr 25; przedruk (zmieniony) w: H. Mortkowicz-Olczakowa, O Stefanie Żeromskim. Ze wspomnień i dokumentów, Warszawa 1964, s. 263.

${ }^{5}$ Dwudziestego szóstego maja 1916 roku Władysław Prokesch pisał do Żeromskiego: „Przez pośrednictwo p. Terleckiego przesyłamy Wam resztę rękopisu, jaki otrzymaliśmy od p. Mortkowicza"; BN, rkps akc. 17 218/29.

${ }^{16}$ S. Żeromski, Listy 1913-1918, s. 327.

Z. Goliński, Wstęp, w: S. Żeromski, Pisma zebrane, pod red. Z. Golińskiego, t. 1:

Opowiadania, s. 92

18 S. Żeromski, Listy 1913-1918, s. 328.

${ }^{19} \mathrm{H}$. Mortkowiczówna, Dramatyczne dzieje rękopisu.

S. Żeromski, Listy 1913-1918, s. 326-327.

Ibidem, s. 333

Ibidem, s. 336

23 Ibidem.

BN, rkps akc. 13 665/4-6

BN, rkps akc. 13 665/4, k. 68-68v. 


\section{Beata Utkowska}

${ }^{26}$ Cyt. za: H. Mortkowiczówna, Dramatyczne dzieje rękopisu.

27 Ibidem.

${ }^{28}$ Dwudziestego szóstego maja, przesyłając pisarzowi rękopis do skrócenia, Prokesch prosił „o jak najrychlejsze poprawienie i odesłanie przez okazję, aby zwłoka [w druku] nie była zbyt długa"; BN, rkps akc. 17 218/29.

${ }^{29}$ BN, rkps akc. 13 665/4, k. $75 v-76$.

${ }^{30}$ S. Żeromski, Zamieć, Warszawa 1916, s. 83.

${ }^{31}$ Ibidem, s. 85.

${ }^{32}$ BN, rkps akc. $13665 / 5$, k. $10 \mathrm{v}$

33 Ibidem, k. $12 v$

${ }^{34}$ Ibidem, k. 25v

${ }^{35}$ S. Żeromski, Zamieć, s. 114

${ }^{36}$ BN, rkps akc. $13665 / 5$, k. 29

${ }^{37}$ Mortkowiczówna streściła ten rozdział w swoim artykule i jej streszczenie pokrywa się z wersją brulionowa.

38 S. Żeromski, Listy 1913-1918, s. 335-336.

${ }^{39} \mathrm{BN}$, rkps akc. $13665 / 5, \mathrm{k} .10 \mathrm{v}$. kowany fragment powieści „Zamieć”), „Twórczość” 2013, nr 4.

41 S. Zeromski, Listy 1913-1918, s. 328.

42 Z. Goliński, Wstęp, s. 33-34 i 87.

${ }^{43}$ S. Żeromski, Pisma, pod red. S. Pigonia, t. 17: Walka z szatanem, t. 2: Zamieć, Warszawa 1948, s. 236. Podobnie w późniejszych wydaniach Czytelnika z 1956 i 1966 roku.

${ }^{44}$ Materiały Władysławy Wasilewskiej, BG UJK, rkps Przyb. 28/2011.

${ }^{45}$ B. Utkowska, Literackie i rodzinne tajemnice z Wielką Wojną w tle. O „Walce z szatanem” Stefana Żeromskiego, „Napis” 2013, seria 19.
${ }^{40}$ Ibidem, k. 62-72. Zob. też: Z. J. Adamczyk, Spotkanie w domu schadzek (nieopubli-

"

42. Silechetry sitandoir?

13. - Preshork ad. n. 1909

9. Proponowone ingerencje $i$ ich krórkie uzasadnie

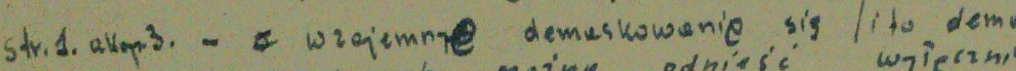
○)

c) nuckowgith moince odniesic nauki buriveryinej; w stosunks neuthe butiver 7 ine torskig:

ehup. K. Wydeie sis, ie eutor nie podst

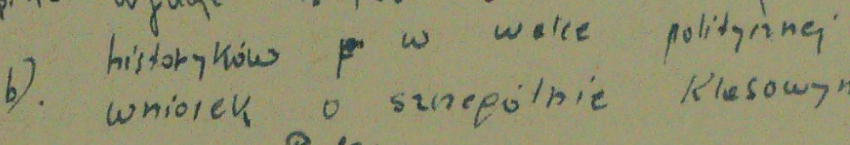
a w Polsec.

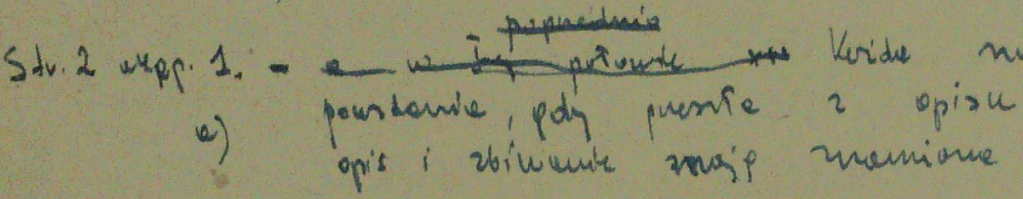

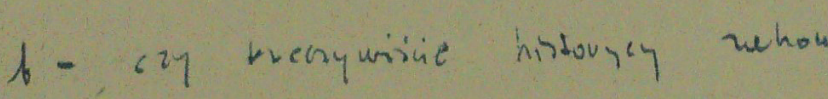

Stu.3 - Sfurmutowome concimnici mptne b) wydage sis, ic poolotne divelleme

Sh.5. e). carkthe vetorme nie zlikundow nic sivisnit chiope, zeycolmén, wiwith ? ism skkllow the $8-, \quad(27 \div)$ ?

10. Wniosek recenzento (niepotrzebne skreślici)

a) daiatic zazmalenia

br rrie adrietic-zezwoterio

c) udzielić zezwolenio po dokononiu ingerenc

11.

12. Decyzjo:

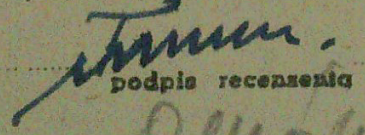

Sztuka Edycji 1/2015 